\title{
Default and the Crime of Fraud in Business Contract in Indonesian Laws
}

\author{
Elza Syarief \\ Universitas Internasional Batam, Jl. Gajah Mada, Baloi - Sei Ladi, Batam, Riau Islands 29442, Indonesia
}

\begin{abstract}
In a business case when a company had a legal problem to distinguish between fraud and default, the company need further legal analysis to see the difference between the two. This study aims to identify default and the crime of fraud in business contract in Indonesian laws. The results showed that every action that is categorized as a criminal case must have an act (actus reus) and malicious intent (mens rea). If actus reus is an act against the law, then what is meant by mens rea are things that include elements of the criminal act. There are 2 indicators to distinguish whether the act committed in the context of the agreement constitutes default or fraud. First, when, that is, if there is a situation that is not right before the agreement is closed/agreed upon, it is fraud, on the contrary if after the agreement is closed then it is default. Second, there must be a series of lies spoken before the agreement is closed before it can be said as fraud is not enough with one lie.
\end{abstract}

Keywords: default, business crime, business contract, business law, Indonesia

DOI: $10.7176 /$ JLPG/107-03

Publication date:March $31^{\text {st }} 2021$

\section{Introduction}

In a business case when a company had a legal problem to distinguish between fraud and default, the company need further legal analysis to see the difference. First, different legal domains. a claim for default is in the realm of civil law, while fraud is in the realm of criminal law. Second, differences in definitions and elements. Differences in the definition of the elements of Default and Fraud are as follows: According to the opinion of legal experts, the elements of default are not doing what he was supposed to do, carrying out what he promised, but not as promised, doing what he promised but was too late, doing something that the agreement is not allowed to do. The criminal act of fraud is regulated in the Criminal Code, Chapter XXV concerning Fraud (bedrog), Article 378 of the Criminal Code which has the elements of benefiting the company by breaking the law, mobilizing people to surrender something or to give debt or write off receivables, and using any of the attempts or means of deception (using fake names, tricks, series of lies).

Indonesian Supreme Court Jurisprudence dated 26 July 1990 No.1601.K/Pid/1990 which stated: "The main element of the delict of fraud (Article 378 of the Criminal Code) lies in the methods/efforts that have been used by the perpetrator of the delict to move other people to hand over something. "The basic principle of the criminal act of fraud is dishonest means of obtaining property, namely by means of cheating/trickery. Also, dishonest in obtaining benefits or benefits through trickery so that the victim feels cheated". Third, the difference in goodwill between the parties. The fundamental difference between a default lawsuit case lies in the good will or goodwill between the parties or the good faith is stated in a mutually beneficial agreement either before a public official or made by a public official signed by both parties, from the start it is reflected in the motivation of the parties to cooperate. Whereas in the criminal act of fraud from the beginning it was based on malicious intent or committing a crime. In order to gain profits, it is done by deception as if it were true or against the law, so that other people suffer material or immaterial losses. Fourth, differences in how to file claims for losses. The method of filing a claim for compensation due to default is through a civil suit to the District Court while a criminal charge due to an act of fraud is through a report on alleged criminal acts through the Police. So, when the company face business problems that result in losses, the company will find it easier to distinguish between fraud or default by seeing the good intentions between parties by reading this article. Therefore, the company should not become a victim of default but be convicted by someone else. Many studies have conducted the analysis regarding the default and business crime in many countries (Ayres \& Gertner, 1989; Ware, 1998; Graves, 2011; Posner, 2005; Steele, 2009; Badriyah et al., 2021). This study aims to identify default and the crime of fraud in business contract in Indonesian laws.

\section{Sample Case}

A provides a loan to $\mathrm{B}$, then $\mathrm{B}$ will make a refund along with the interest by issuing a check with the date agreed between $\mathrm{A}$ and $\mathrm{B}$. If $\mathrm{B}$ issues a check that he realizes that the check will never have any funds, even though he has promised A that the check has funds, then B's act could be categorized as fraudulent by means of trickery. This is as confirmed in the Supreme Court Jurisprudence No. $133 \mathrm{~K} / \mathrm{Kr} / 1973$ dated 15-11-1975. Unless B knows that the check had funds at the time of issuance and but on the due date the funds are not there, then B's act can only be categorized as pure default. By using legal basis of Civil Code (Burgerlijk Wetboek, Staatsblad 1847 No. 
23) and Criminal Code (Wetboek van Strafrecht, Staatsblad 1915 No. 73), the decisions made are Supreme Court Jurisprudence No. 133 K/Kr/1973 dated 15-11-1975 and Supreme Court Jurisprudence No. 1601.K/Pid/1990 dated 26 July 1990.

Another example showed a case of default become criminal. A and B enter into an agreement in which A borrows funds from B in the amount of IDR.40,000,000.00 with an interest of $0.5 \%$ per month. The funds will be returned with an instalment scheme every month and payment every 15 th. In the first six months, A carried out his obligations in accordance with the agreement that was agreed by both parties at the beginning. However, in the following month, A was unable to fulfil his obligations and continued into the following months. Feeling aggrieved, B decided to take the matter to court. In principle, the accounts payable agreement made by A and B is a civil relationship. This is in accordance with the provisions contained in Article 1754 of the Civil Code concerning the meaning of lending and borrowing, "An agreement in which one party gives the other party a certain amount of goods that are spent due to use on the condition that the latter party will return an amount of the same type and quality". However, cases of violation of the agreement committed by A can be processed criminally if there are elements of fraud and malicious intent in it. If the elements mentioned in Article 378 of the Criminal Code are fulfilled, then the case can be tried on the basis of a criminal offense. In this case, for example, from the beginning, A had indeed had malicious intent to commit fraud using a false name or status, deceived the purpose of using loan funds, or learned that from the beginning he would not be able to fulfil his obligations but still agreed to fulfil his obligations by creating a series of lies (gimmicks) or other things.

However, the case will be different if it turns out that A did an accident. When making the initial agreement, A provides real data and knows that he has funds and is able to do what is his obligation as a borrower. Unfortunately, on the way, something happened that caused him to be unable to carry out his obligations properly such as serious illness, layoffs, or other factors that were completely unexpected and deliberate. As long as A has good intentions to carry out what is his obligation, then B cannot sue this case as a criminal offense. This is done based on the provisions contained in article 19 paragraph (2) of Law no. 39 of 1999 concerning Human Rights which reads, "no one on a court decision may be sentenced to prison or imprisonment based on reasons of inability to fulfil an obligation in a debt agreement". This means that the court cannot convict someone because of their inability to pay debts.

Furthermore, Civil Cases that Become Criminal of Embezzlement. Apart from fraud cases, civil cases that often have the potential to become criminal cases are embezzlement. In Indonesian Criminal Code article 372, it is stated that "anyone who deliberately and illegally owns something that belongs wholly or partly to another person, but is under his control not because of a crime, is threatened with embezzlement, with a maximum imprisonment of four years or a maximum fine nine hundred rupiah.

Related to this, Soesilo (1994) also explained in his book the Criminal Code and its Complete Comments Article by Article that, embezzlement is a crime that is almost the same as theft in article 362 of the Criminal Code. What is the difference between embezzlement and theft is in the fact that theft, the goods that are owned are still not in the hands of the thief and must still be taken, while in embezzlement, the goods are already in the hands of the perpetrator. That is information about criminal and civil law and when a civil case becomes a criminal. Basically, any party who feels aggrieved can report to the authorities to carry out a criminal process even though the party who violates the agreement does not have bad intentions. However, law enforcers must still be observant and wise in deciding whether the case can be followed up as a criminal or not.

Last example was given by that it is a fraud crime that begins with defaults paid by a check that does not have funds in the sale and purchase agreement (Case Study of Sri Handayani and Prapto Hadi). Starting from an incident about a criminal act of fraud which began with a default paid by a check that had no funds in the car sale and purchase agreement. The non-performing act paid by a check with no funds was carried out by Sri Handayani categorized as a criminal act of fraud. Regarding the car BPKB that was guaranteed to PT. SMAC (third party), Central Jakarta District Court Decision No. 2292/Pid.B/2009/JKT.PST Jo. Jakarta High Court Decision No. 61/PID/2010/PT. DKI Jo. Supreme Court Decision No. 1881 K/PID/2010 can be used as the basis for Prapto Hadi, SH., MH to demand that the third party submit the proof of ownership of the vehicle (BPKB). It is known that Sri Handayani's action cannot be categorized as a default. This is because Sri Handayani as a debtor has committed acts against the law within the scope of civil law, which is then due to lies, giving a blank check, and the delivery of a vehicle without a Motor Vehicle Owner's Book (BPKB), causing losses to Prapto Hadi, so that acts against the laws that were originally within the scope of civil law become the scope of criminal law, namely fraud. Central Jakarta District Court Decision No. 2292/Pid.B/2009/JKT.PST Jo. Jakarta High Court Decision No. 61/PID/2010/PT. DKI Jo. Supreme Court Decision No. 1881 K/PID/2010 stated that the Toyota Avanza car with Police Number B 2410 DN belonging to Sri Handayani was handed over to Prapto Hadi. This Judge's decision could be the basis for Prapto Hadi to sue Sri Handayani and PT. SMAC (third party) simultaneously in one lawsuit to punish Sri Handayani and PT. SMAC to submit the BPKB for a Toyota Avanza with Police Number B 2410 DN, and if Sri Handayani and PT. SMAC could not hand over the BPKB so Sri Handayani was sentenced to pay compensation to Prapto Hadi. 


\section{Definition of Default}

Default can be interpreted as inadequate performance due to debtor's fault either on purpose or negligence. According to Satrio (2009), default is a situation where the debtor does not fulfill his promise or does not fulfill it properly and all of it can be blamed on him (Craswell, 1989). Harahap (2004) stated that default is an implementation of an obligation that is not timely or done inappropriately, thus creating an obligation for the debtor to provide or pay compensation (schadevergoeding), or by default by one party, the other party can demand cancellation of agreement (Stolp, 2007; Miller, 2013).

Fraud means dishonest or untrue or false, fake, etc. with the intention of misleading, deceiving or seeking profit. The act of fraud is an act that is detrimental to other people so that it is an act that can be subject to criminal law. The definition of fraud above illustrates that the act of fraud has several forms, either in the form of lies or in the form of actions with the intention of seeking one's own benefit from others. The benefits in question are either in the form of material benefits or benefits that are abstract in nature, for example removing someone from their position. In the Criminal Code, to be precise, Article 378 of the Criminal Code stipulates the crime of fraud in a general form, while those listed in Chapter XXV of Book II of the Criminal Code contain various forms of fraud against property formulated in several articles, each of which has specific names. All articles in Chapter XXV are known as bedrog or people's actions. The crime of fraud (bedrog) is contained in Chapter XXV of Book II of the Criminal Code, from Article 378 to Article 349. The original title of this chapter is bedrog which many experts have translated as fraud, or some have translated it as acts of people.

The word fraud itself has two meanings. Fraud in a broad sense, namely all crimes defined in Chapter XXV of the Criminal Code. Fraud in the narrow sense, is a form of fraud formulated in Article 378 of the Criminal Code (main form) and Article 379 of the Criminal Code (special form). In Article 378 of the Criminal Code which regulates the following: Anyone who with the intention of seeking to benefit himself or another person against his rights, whether by using a false name, either by action and deception or by means of false speech, persuades people to give something, incurs a debt or writes off a debt, is threatened because fraud with a maximum imprisonment of four years. The definition of fraud according to the above opinion, it is clear that what is meant by fraud is a trick or a series of lies so that someone feels deceived by what seems to be true. Usually, a person who commits fraud is explaining something that seems true or has happened, but in fact his words are not in accordance with reality, because the goal is only to convince the person who is the target to follow his wishes, while using a false name so that the identity of the person concerned is not known Likewise, using a false position so that people are sure of what he is saying. Is the act of default is included in a fraud offense If viewed from the element of default it is not carrying out any performance at all; Implement but not on time (too late); Carry out but not as promised; then the element of default meets Article 378 of the Criminal Code which regulates the following; Anyone who with the intention of seeking to benefit himself or another person against his rights, whether by using a false name, either by action and deception or by means of false speech, persuades people to give something, incurs a debt or writes off a debt, is threatened because fraud with a maximum imprisonment of four years.

The application of criminal sanctions against someone who commits default is by conducting mediation efforts with the existence of a peace deed. In principle, a legally made peace deed will be binding and have the same legal force as a court decision that has permanent legal force and an appeal cannot be made so that if someone has made an appeal but if the person does not carry out the peace decision, then that person can complain to the police in accordance with Article 1 paragraph (25) of the Criminal Procedure Code, which is: Notification accompanied by a request by the interested party to the competent authority to take legal action against a person who has committed a criminal offense against him. In the case of complaints, the authorized parties must first qualify whether the complaint is an offense or not by looking at the capacity of the complainant first. So that the complainant can submit a complaint to the Police by showing the conciliation decision or the daring deed to be used as evidence as the basis for the complaint so that it complies with Article 184 of the Criminal Procedure Code regarding Witness Statement; Expert statement; Letter; Instructions; Statement of the defendant. And if there are 1842 conditions that are fulfilled from Article 184 of the Criminal Procedure Code, then the police can make an arrest if there are 2 sufficient preliminary evidences in accordance with Article 17 of the Criminal Procedure Code.

\section{Result and Analysis}

Default can be in the form of: (i) not carrying out what was agreed; (ii) carrying out what was promised but not as it should be; (iii) carrying out what was promised but too late; or (iv) doing something that the agreement is not allowed to do. The party who feels aggrieved due to default can demand fulfilment of the agreement, cancel the agreement or ask for compensation from the party who did the default. Compensation for losses can include costs that have actually been incurred, losses incurred as a result of the default, and interest. This default is in the field of civil law, while fraud is included in the field of criminal law (criminal offense) (Article 378 Criminal Code). A person is said to have committed fraud if he against his right intends to benefit himself or others. 
"Against rights" here can be exemplified using fake names, false speeches, etc. In fraud there is an element of intent in the perpetrator. Meanwhile, people who are accused of default may not have the intention to commit default. It is possible that he could not carry out the agreement because of things beyond his ability. For example, in the agreement, on the 4th, A had to hand over a batch of rice to B. However, because the village where he lived was hit by a flood, A could not hand over the rice. In this case A has defaulted against B.

There are 2 cumulative indicators to distinguish whether the act is fraud or default in the context of the agreement: First: if there is an untrue situation before the agreement is closed/agreed upon then it is fraud, conversely if after the agreement is closed then it is default. Second: Way, there must be a series of lies that are spoken at the time before the agreement is agreed to be said as fraud is not enough with one lie. Simply put, there are 2 indicators that are cumulative both must be met to distinguish whether a case is default or fraudulent in the context of its relationship with the agreement. The characteristics of default and fraud are rooted in the legal relationship that occurs between the parties, which is always "preceded" by a contractual legal relationship. The location of the boundary between default and fraud in the context of the agreement at the "tempus delicti" or when the agreement/contract is closed/agreed upon by both parties (Deigo, \& Tawang, 2020; Astuti, 2013; Seba, 2017). If after (post factum) the contract is closed it is known that there is a trick, a series of lies or a false condition from one of the parties, then that act is default. If before the (ante factum) contract/agreement is closed there is a trick, a series of lies or a false condition from one of the parties, the condition or trickery has been hidden by one of the parties, then that act is fraud. The existence of a series of false words or false circumstances before or after the contract is closed/agreed upon determines a person's "intention", if before the contract is closed from the beginning there has been bad intentions then this is a fraud. Conversely, if after the contract is closed someone's bad intentions arise, then this is an act of default. II. Deception and a series of lies can be proven untrue since the act/statement was made, while breaking a promise must be proven untruthful at a certain time after the promise was made. Deception and a series of lies can be done to conditions in him or circumstances outside him, while the promise is always dependent on his ability even though that ability is intended to make others do or not do something. Apart from what has been described above the element of "a series of lies" or according to Soesilo (1994) is referred to as "fabrication of lies" in Article 378 of the Criminal Code is translated as a form of "several lies" or a lot of lying words must be used in such a manner. such that one lie can be covered by another lie and the whole story is something that seems true. To be able to fulfil the element of "a series of lies" it is not enough to just have one lie, but it must be an accumulation of several lies that support and complement each other so that they are able to move people to surrender goods, create debts or write off receivables. Supreme Court Jurisprudence dated 26 July 1990 No. 1601.K/Pid/1990 states: "The main element of the delict of fraud (Article 378 of the Criminal Code) lies in the methods/efforts that have been used by the perpetrator of the delict to move other people to hand over something." The basic principle of the criminal act of fraud is a dishonest way to acquire property, namely by means of fraud. Also, dishonest in obtaining benefits or benefits through trickery so that the victim feels cheated.

\section{Conclusion}

The results showed that every action that is categorized as a criminal case must have an act (actus reus) and malicious intent (mens rea). If actus reus is an act against the law, then what is meant by mens rea are things that include elements of the criminal act. Some also can be included as crime if they have indeed malicious intent to commit fraud using a false name or status, deceived the purpose of using loan funds, from the beginning they would not be able to fulfill the obligations but still agreed to fulfill his obligations by creating a series of lies. In the criminal act of fraud, malicious intent can be identified from the start by comparing what is said or done contrary to one's objective conditions and abilities, besides the intention that can be known from the start is its unlawful nature

Based on the description, it can be understood that there are 2 indicators to distinguish whether the act committed in the context of the agreement constitutes default or fraud. First, when, that is, if there is a situation that is not right before the agreement is closed/agreed upon, it is fraud, on the contrary if after the agreement is closed then it is default. Second, there must be a series of lies spoken before the agreement is closed before it can be said as fraud is not enough with one lie.

\section{References}

Astuti, M. P. (2013). Penentuan Tempus Dan Locus Delicti Dalam Kejahatan Cyber Crime (Studi Kasus Di Reskrimsus Polda Jateng). Under Graduates thesis, Universitas Negeri Semarang.

Ayres, I., \& Gertner, R. (1989). Filling gaps in incomplete contracts: An economic theory of default rules. The Yale Law Journal, 99(1), 87-130.

Badriyah, S. M., Suharto, R., Saraswati, R., \& Wafi, M. S. (2021). Implementation of the Constitutional Court Decision Regarding the Execution of Fiduciary Guarantees and Inclusion of Default Clauses in Indonesia. International Journal of Criminology and Sociology, 10, 33-38. 
Craswell, R. (1989). Contract law, default rules, and the philosophy of promising. Michigan Law Review, 88(3), 489-529.

Deigo, P. A., \& Tawang, D. A. D. (2020). analisis limitasi locus dan tempus delicti dalam delik penipuan yang terjadi di luar negeri (studi putusan mahkamah agung nomor 58/PK/pid/2018). Jurnal Hukum Adigama, 3(1), 1267-1291.

Graves, J. M. (2011). Arbitration as contract: The need for a fully developed and comprehensive set of statutory default legal rules. Wm. \& Mary Bus. L. Rev., 2, 227.

Harahap, M. Y. (2004). Hukum acara perdata: tentang gugatan, persidangan, penyitaan, pembuktian, dan putusan pengadilan. Jakarta: Sinar Grafika.

Miller, S. K. (2013). The best of both worlds: Default fiduciary duties and contractual freedom in alternative business entities. J. Corp. L., 39, 295.

Posner, E. A. (2005). There are no penalty default rules in contract law. Fla. St. UL Rev., 33, 563.

Satrio, J. A. (2009). What is the Bioeconomy?. Research Workshop on Sustainable Biofuel Development in Indonesia, Progress So Far and Future Applied Research Opportunities. February 4-5, 2009, Jakarta, Indonesia.

Seba, M. J. (2017). tinjauan yuridis terhadap penerapan sanksi atas penganiayaan berencana yang mengakibatkan kematian dalam kuhp. Lex Administratum, 5(9).

Soesilo, R. (1994). Kitab Undang-undang Hukum Pidana (KUHP) serta komentar-komentarnya lengkap pasal demi pasal. Bogor: Politea.

Steele, M. T. (2009). Freedom of Contract and Default Contractual Duties in Delaware Limited Partnerships and Limited Liability Companies. American Business Law Journal, 46(2), 221-242.

Stolp, M. M. (2007). Ontbinding, schadevergoeding en nakoming. De remedies voor wanprestatie in het licht van de beginselen van subsidiariteit en proportionaliteit. Deventer: Kluwer.

Ware, S. J. (1998). Default rules from mandatory rules: Privatizing law through arbitration. Minn. L. Rev., 83, 703. 